\title{
Composition and Functional Diversity in Bird Communities in a Protected Humid Coastal Savanna
}

\author{
Alfan A. Rija, Abubakari S. Mgelwa, Robert B. Modest, and Shombe N. Hassan \\ Department of Wildlife Management, Faculty of Forestry and Nature Conservation, Sokoine University of Agriculture, \\ P.O. Box 3073, Chuo Kikuu, Morogoro, Tanzania \\ Correspondence should be addressed to Alfan A. Rija; al.rija10@gmail.com
}

Received 8 August 2015; Revised 2 November 2015; Accepted 16 November 2015

Academic Editor: Mauro Fasola

Copyright (C) 2015 Alfan A. Rija et al. This is an open access article distributed under the Creative Commons Attribution License, which permits unrestricted use, distribution, and reproduction in any medium, provided the original work is properly cited.

\begin{abstract}
Our current understanding of the vertebrate communities of a newly gazetted Tanzanian coastal national park is limited and strongly taxonomically biased towards large mammals. We conducted bird assessments in three sites in Saadani National Park using species lists to analyze some parameters to inform biodiversity conservation in the area. We recorded 3112 individuals in 268 species falling in 66 families, including 2 endangered, 2 vulnerable, and 6 near threatened species. Both species richness and species diversity varied between sites. Species relative abundances were not different between the sites although some functional groups, especially granivores, were more abundant than others. Bird assemblages included 21 forest specialists (FF-species), 35 forest generalists (F-species), and 68 forest visitors (f-species) overlapping among bushland, wooded grassland, grassland, and thickets suggesting presence of important microhabitats for the forest-associated species in this ecosystem. Bird species richness in a feeding guild also showed marked overlap between habitats suggesting availability of rich food resources for the birds. This paper highlights the importance of maintaining a structurally heterogeneous landscape to sustain diverse bird communities in the area.
\end{abstract}

\section{Introduction}

The coastal habitats of Eastern Tanzania are known for their high biological diversity and endemism $[1,2]$ but are increasingly threatened due to illegal anthropogenic resource extraction, for example, $[3,4]$. Consequently these areas face potentially imminent local species extinctions. There is increasing attention focused on addressing the threats to the area by scientists [2-4] and the conservation agency, for example, [5]. The evidence base for justifying conservation action can be drawn from recent scientific publications on various taxa including invertebrates, for example, [6], vertebrates, for example, [7], and plants, for example, [8]. An example of the increased recent conservation efforts in coastal Tanzania is the incorporation of Saadani Game Reserve, Mkwaja Ranch, and Zaraninge forest into a national park. Since its gazettement in 2005, Saadani National Park has been the subject of several ecological studies focusing on large ungulate populations and plants, for example, [911]. Thus, the existing knowledge about this area is limited and arguably biased towards large mammals. Thus increased understanding of the other biodiversity present in this recently gazetted protected area is important for predicting future population trends and assessing the required level of habitat management [9]. This is especially important as the area had experienced large scale decrease in the cover of bushland and a significant encroachment of bushes in some parts due to cattle grazing that persisted for nearly 50 years $[12,13]$. The reduction of such pressures may have resulted in significant turnover leading to high species richness and/or altered community assemblages $[9,11]$. Despite the fact that many external sources of anthropogenic pressure have been minimized following protection, the area continues to receive some internally generated disturbance such as intentional or accidental fires and illegal resource extraction persists. The area is also not immune to potential negative influences of climate change that affect many ecosystems worldwide [14]. Altogether, such factors are likely to influence community dynamics at local spatial scales regardless of whether the area is under protection or not. In this study, we assessed 


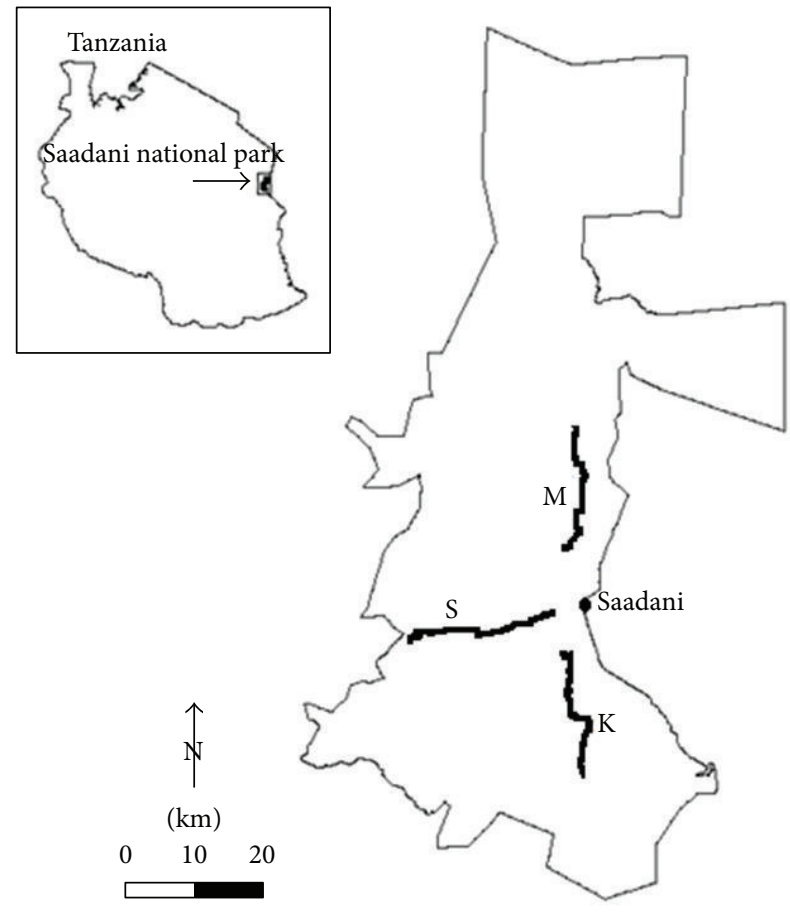

FIGURE 1: Map of Saadani National Park showing proximate location where bird sampling was conducted. S: Saadani Gate, M: Mkwaja, and K: Kinyonga (see text for more details).

bird communities in Saadani National Park to determine a number of parameters that will be used for future monitoring work. Our objectives were to (i) determine the species composition, abundance, richness, and diversity and assess the conservation status of birds and (ii) investigate the relative importance of the different habitats in supporting various bird guilds.

\section{Material and Methods}

2.1. Study Area and Sampling Protocol. Located between $5^{\circ} 38^{\prime}$ and $6^{\circ} 16^{\prime}$ south and $38^{\circ} 36^{\prime}$ and $38^{\circ} 53^{\prime}$ east, Saadani National Park stretches along the western coast of the Indian Ocean and lies about $80 \mathrm{~km}$ north of Dar es Salaam city, Tanzania. The park covers 1,137 square kilometers and is bordered by 10 villages. It is the only park in Tanzania with a marine zone (Figure 1). The park cuts across the Tanga and Coast regions and is situated in the Pangani and Bagamoyo Districts, with a small portion in Handeni district. The park comprises the former Saadani Game Reserve, Zaraninge Forest Reserve, and the Mkwaja Ranch. The largest part $\left(671 \mathrm{~km}^{2}\right)$ is mostly savanna [11]. The main vegetation types are bushland, grassland, thicket-grassland mosaic, forest, and wooded grassland. Detailed description of the vegetation types and a historical perspective of the area have been provided elsewhere [12, 13]. The study area receives bimodal rainfall characterized by short rains from October to December and heavy rains from March to May peaking mainly in April. Annual rainfall averages at $1300 \mathrm{~mm}$ /year with minimum and maximum at
$1000 \mathrm{~mm} /$ year and $1500 \mathrm{~mm} /$ year, respectively [4]. The long dry season is between June and September with a shorter dry period during January and February. The average temperature is $25^{\circ} \mathrm{C}$ during the dry season and varies considerably during the wet season [1]. This study was conducted in three localities, namely, (i) Kinyonga, an area extending from Kinyonga campsite to Saadani village including Tourism headquarter office in the South-east, (ii) Saadani entry gate, extending from the tourism headquarter office to Mvave entrance gate, and (iii) an area extending from the tourism headquarters office towards Mkwaja park headquarters in the northeast. In this paper we use Kinyonga, Saadani Gate and Mkwaja sites to infer these study blocks or zones (Figure 1).

2.2. Sampling of Birds. We used the Mackinnon list [15] to survey birds in the months of August and September, 2012, using transects walks spaced at least $2 \mathrm{~km}$ apart across each study block. Nine transects each measuring at least $3.5 \mathrm{~km}$ were surveyed along a stretch of $22 \mathrm{~km}$ in Kinyonga, eight in Saadani Gate $(16 \mathrm{~km})$, and eight transects along the Mkwaja block $(23 \mathrm{~km})$. The Mackinnon list method enables the calculation of species discovery curve and index of relative abundance [16]. It is a much preferred method for inventory studies due to its relatively less susceptibility to differences in ability and concentration of the observer and results are unaffected by both long time used in identifying a bird when running the transect and variation in bird's activity patterns during sampling [15]. This method has also been used to assess the avifauna diversity in the southern highlands and Udzungwa Mountains of Tanzania, for example, [17, 18].

At random starting points, the observers scanned the area along the north-south and east-west directions recording all the birds seen or heard with the aided pair of binoculars (Kite Petrel; $10 \times 42$ ) and bird field guide books [1921]. From these starting points we walked westwards from the Pangani-Bagamoyo road and south or northward from Mvave-Saadani road identifying birds upon sighting and/or hearing. We used various strategies including searching in the different habitats making direct observations, flushing birds from valleys, long grass, and bushes, walking at different speeds, and recording bird calls to aid correct identification [15]. These strategies increased bird detection across various habitats and different times of the day that could have been low due to changes in activity pattern of birds [15]. On each first Mackinnon list, birds were recorded without repetition until a predetermined number of species was completed. The lists were of similar length (20 species) to enable comparison of some ornithological parameters between sites [15] and constituted at least fifteen species as recommended for a site for meaningful results $[15,16]$. We adapted the traditional Mackinnon lists method [22] to record number of individuals of each bird species encountered for subsequent calculation of the species diversity [23]. Sixty-eight lists, 20 species each, were collected during the survey and the lists were considered as independent sampling units during data analysis. We also recorded habitat types at positions where the bird species were sighted and bird feeding guild of each species was assigned with the help of the published literature $[4,24]$. Bird guild classification, feeding (insectivores, nectarivore, etc.), 
and ecological groups (forest specialists, generalists, etc.) are hereby defined and assigned following [24]. Data collection started no later than 7.00 a.m. and ended at around 5.30 p.m. for about 10 hours of survey per day. All field surveys were conducted over six days.

2.3. Data Analysis. A species discovery curve was plotted using bird lists as the unit of survey effort against the cumulative total number of species recorded. Data were truncated to the minimum of 22 lists to enable comparison between localities as the number of lists varied slightly between sites. An index of relative abundance (IRA) was calculated for each species in the area as the fraction of lists on which a species occurs. This value can range from 0 for unrecorded species to 1 for frequently occurring species that were observed on every list [15]. A graph of species relative abundance was plotted and a Kruskal-Wallis test was performed to test for the difference between sites. Further, we used the program EstimateS [25] on abundance-based data to estimate species richness and species diversity of the surveyed areas taking individual lists as independent samples. To evaluate richness and diversity indices, we set the number of runs to 100 to get smoothed curves at all levels of species accumulation [23]. Randomization protocol was set at "randomization with sample replacement" with the respective diversity index setting to obtain species richness and Shannon diversity index. To understand effectiveness of our sampling effort on species inventory completeness in the surveyed area, we used the formula $\widehat{S}=S_{O}+F 1^{2} / 2 F 2$, where $S_{O}$ is the number of observed species, $F 1$ is the number of species observed only once, $F 2$ is the number of species observed twice in the lists, and $\widehat{S}$ is the richness estimator based on Chaol estimators [26]. Inventory completeness was then calculated using the formula $C=S_{O} / \widehat{S}$. Further, species diversity between localities was compared using KruskalWallis test while differences in species richness between three localities were examined using nonparametric analysis of variance [27] after confirming normality in distribution. Furthermore, we collated information from the available literature to identify feeding and habitat guilds of each species and their conservation status based on the IUCN red list. Finally, we analyzed species habitat ecology or degree of forest dependence and feeding guilds among different habitats [4, $24,28]$. To understand the relative importance of the habitat types in supporting various bird functional groups (habitat ecology and feeding groups), we employed various statistical tests. We compared separately both the FF- and F-species data between bushland and wooded grassland habitats using the $t$-test. The Wilcoxon sign rank test was also applied individually on the $\mathrm{f}$ - and s-species data among the same habitats and between grassland and thicket grassland on the s-species data. We did not test for other habitats because the data were very few. Further, to gain more insights into the importance of the habitats for the bird feeding guilds, Wilcoxon sign rank test was performed separately to compare insectivores and granivores abundances between bushland and wooded grassland habitats. On the other hand, a $t$ test was used for the piscivores and predatory bird guilds.

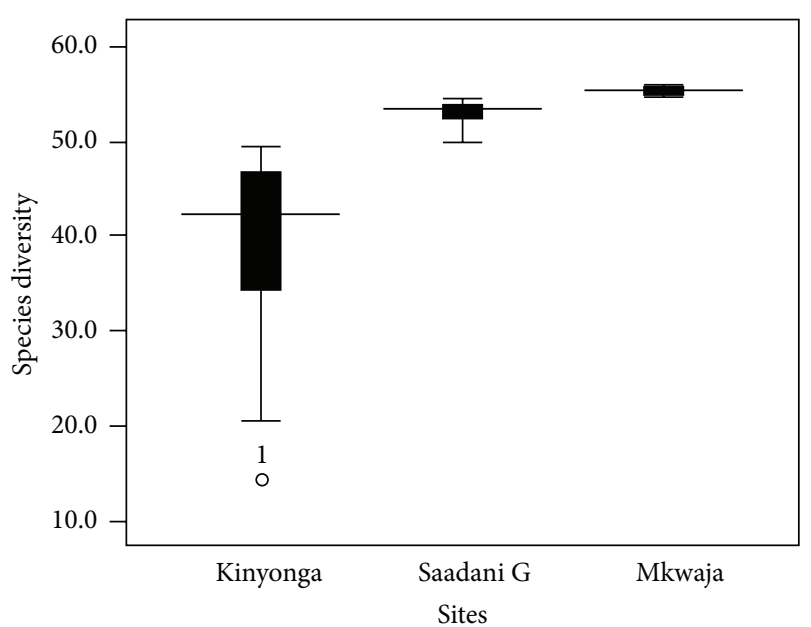

FIgURE 2: Species diversity of the three sites in Saadani National Park with Mkwaja showing the highest diversity index suggesting the presence of important resources for the survival of most bird species in the study area. Error bars are presented with 95\% confidence interval.

Similarly, no tests were done for the thicket grassland, bare soil, and grassland habitats due to few data. All statistical analyses were performed using SPSS v 16.

\section{Results}

3.1. Species Composition, Relative Abundance, and Richness. We recorded 268 species (3112 individual birds) in 66 families with $31.9 \%$ of all birds recorded in Kinyonga and 32.4\% around Saadani Gate, and Mkwaja contributed 35.6\%. Of these species twenty-nine have not been recorded before in previous observations by other scientists (Table 1). Species relative abundance ranged from 0.00 to 0.80 . About $20 \%$ of all species recorded had indices of relative abundance below 0.02 . Streptopelia capicola was the most abundant species, recorded at $80 \%$ of all the lists across the sampled area. There was a significant difference in species relative abundance between the sites (Kruskal-Wallis $\chi^{2}=27.016 ; \mathrm{df}=2 ; P=$ 0.001 ; median IRA $=0.224$ ). Also, within individual sites, a significant difference was recorded between the observed and expected number of species recorded within the species lists (Kinyonga, $\chi^{2}=672.8, \mathrm{df}=11, P=0.0001$; Saadani Gate $\chi^{2}=602.3, \mathrm{df}=12, P=0.0001$; Mkwaja $\chi^{2}=699.2$, $\mathrm{df}=12, P=0.0001)$. Furthermore, species diversity varied significantly between the sites, with Mkwaja recording the highest species diversity $(\alpha$-diversity $=55.17 \pm 2.09)$ and Kinyonga the lowest $(\alpha$-diversity $=39.26 \pm 3.06)$ (KruskalWallis $\chi^{2}=44.0 ; \mathrm{df}=2 ; P=0.0001$; median $=53.45$, Figure 2). The estimated mean richness was $191.47 \pm 11.12$ species and Shannon diversity index was $4.31 \pm 0.08$ on the combined data across the surveyed area. Also, species richness estimates were the highest in Mkwaja and lowest in Kinyonga (Kruskal-Wallis $\chi^{2}=44.0 ; \mathrm{df}=2 ; P=0.0001$; median $=211.78)$. Our sampling effort recorded $91.3 \%$ of all the species present in the area (Figure 3). 
TABLE 1: Relative frequency and guild classification of the twenty-nine bird species that have not been recorded before in Saadani National Park. Previous sightings have been reported in [4].

\begin{tabular}{|c|c|c|c|c|c|c|}
\hline \multirow{2}{*}{ Common name } & \multirow{2}{*}{ Scientific name } & \multirow{2}{*}{ Relative frequency } & \multirow{2}{*}{ Feeding guilds } & \multicolumn{3}{|c|}{ Habitat guilds } \\
\hline & & & & Kinyonga & Saadani Gate & Mkwaja \\
\hline African white-backed vulture & Gyps africanus & 0.2 & Predators & & $\mathrm{s}$ & \\
\hline Red-billed hornbill & Tockus erythrorhynchus & 0.2 & Omnivores & & s & \\
\hline African grey hornbill & Tockus nasutus & $0.8,0.5,0.4$ & Insect-Frugivores & s & s & s \\
\hline Grey-headed kingfisher & Halcyon leucocephala & 0.2 & Piscivores & & & $\mathrm{f}$ \\
\hline Black-and-white cuckoo & Oxylophus jacobinus & 0.2 & Insectivores & & $\mathrm{f}$ & \\
\hline Yellowbill & Ceuthmochares aereus & 0.2 & Grani.-insecti. & & & $\mathrm{F}$ \\
\hline Great sparrowhawk & Accipiter melanoleucus & 0.2 & Predators & & & $\mathrm{F}$ \\
\hline Hildebrandt's francolin & Francolinus hildebrandti & $0.8,0.5$ & Grani.-insecti. & s & s & \\
\hline Red-necked spurfowl & Francolinus afer & $0.5,0.2$ & Grani.-insecti. & & s & s \\
\hline Yellow-necked spurfowl & Pternistis leucoscepus & 0.2 & Grani.-insecti. & & & s \\
\hline Black-fronted bush-shrike & Malaconotus nigrifrons & 0.2 & Insectivores & & & FF \\
\hline Blue-capped cordon-bleu & Uraeginthus cyanocephalus & 0.2 & Omnivores & & & s \\
\hline Cardinal Quelea & Quelea cardinalis & 0.3 & Granivores & s & & \\
\hline Chestnut weaver & Ploceus rubiginosus & $0.3,0.5$ & Granivores & s & s & \\
\hline Grey-backed Camaroptera & Camaroptera brevicaudata & 0.2 & Insectivores & & $\mathrm{f}$ & \\
\hline Winding Cisticola & Cisticola galactotes & $0.3,0.4$ & Insectivores & s & & s \\
\hline Icterine warbler & Hippolais icterina & $0.2,0.2$ & Insectivores & & s & s \\
\hline Eurasian reed warbler & Acrocephalus scirpaceus & $2.6,0.2$ & Insectivores & s & & s \\
\hline Magpie shrike & Urolestes melanoleuca & 0.5 & Insecti.-carniv. & & s & \\
\hline Magpie starling & Speculipastor bicolor & 0.2 & Insecti.-frugi. & & & s \\
\hline Sharpe's starling & Cinnyricinclus sharpii & $0.3,0.2$ & Frugivores & $\mathrm{FF}$ & & $\mathrm{FF}$ \\
\hline Oriole finch & Linurgus olivaceus & 0.3 & Granivores & $\mathrm{FF}$ & & \\
\hline Rufous-naped lark & Mirafra africana & 0.2 & Grani.-insecti. & & & s \\
\hline Shelley's greenbul & Andropadus masukuensis & 0.2 & Grani.-insecti.-nectari. & & $\mathrm{F}$ & \\
\hline Striped Pipit & Anthus lineiventris & 0.7 & Insecti.-graniv. & & & s \\
\hline Yellow-throated Warbler & Phylloscopus ruficapilla & 0.2 & Insectivores & & & $\mathrm{FF}$ \\
\hline Black-throated Barbet & Tricholaema melanocephala & 0.3 & Insecti.-frugi. & s & & \\
\hline Olive Woodpecker & Dendropicos griseocephalus & $1.0,0.2$ & Insectivores & $\mathrm{F}$ & & $\mathrm{F}$ \\
\hline Chestnut-bellied Sandgrouse & Pterocles exustus & $0.5,0.5$ & Grani.-insecti. & $\mathrm{s}$ & s & \\
\hline
\end{tabular}

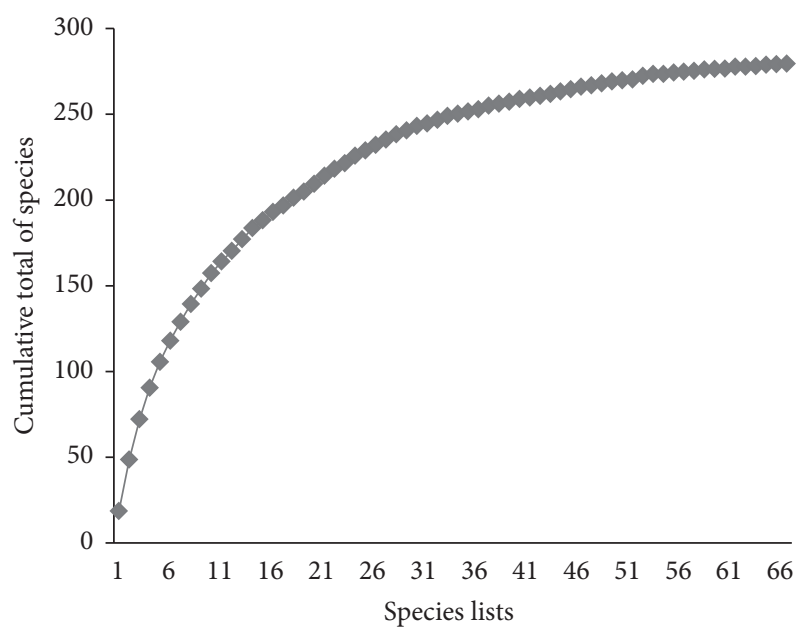

FIGURE 3: Species discovery curve for the sampled bird community suggesting that our sampling effort was nearly complete as more than $90 \%$ of the species available in Saadani National Park were recorded during the inventory process.
3.2. Conservation Status of Birds at Species and Functional Group Levels in the Area. Three of the recorded species were listed as endangered, two as vulnerable, and six as near threatened on the IUCN Red List. The endangered species were distributed in three different feeding guilds, namely, insectivores, nectarivores, and predators while omnivores and predators included a vulnerable species. The near threatened species were in the insectivore, frugivore, insectivorenectarivore, and predator guilds. Most endangered bird species comprised a guild that feed on insects.

3.3. Bird Functional Guilds across the Sites and between Habitat Types. There was diverse niche specialization in the bird community (Table 2). The number of forest dependent bird species was not different across the study sites $(F=$ $0.225, P=0.805)$. There was no evidence of significant difference in the number of forest specialist species between sites $(P>0.05)$. At a habitat level, the number of FF-species supported by both bushland and wooded grassland was also 
TABLE 2: Number of species and their habitat ecology as observed from the study sites.

\begin{tabular}{lccc}
\hline \multirow{2}{*}{ Variable } & \multicolumn{3}{c}{ Study habitat blocks/zones } \\
& Kinyonga & Saadani gate & Mkwaja \\
\hline $\begin{array}{l}\text { Total number of } \\
\text { species }\end{array}$ & 146 & 145 & 186 \\
Total number of & $2^{\mathrm{a}}, 1^{\mathrm{b}}$ & $4^{\mathrm{a}}, 2^{\mathrm{b}}, 1^{\mathrm{c}}$ & $6^{\mathrm{a}}, 1^{\mathrm{b}}, 1^{\mathrm{c}}$ \\
threatened species & 14 & 7 & 18 \\
FF-species & 9.59 & 4.83 & 9.68 \\
\% FF-species & 29 & 21 & 27 \\
F-species & 19.86 & 14.48 & 14.52 \\
\% F-species & 45 & 50 & 63 \\
f-species & 30.82 & 34.48 & 33.87 \\
\% f-species & 58 & 67 & 78 \\
s-species & 39.73 & 46.21 & 41.94 \\
\% s-species & & & \\
\hline
\end{tabular}

Conservation status of bird species is also shown, a: near threatened species, b: vulnerable; c: endangered species. FF: forest specialist species, F: forest generalist, f: forest visitor, and s: savanna/woodland species.

not different (FF-species mean $=0.024 \pm 0.79$ IRA, $t=0.096$, $\mathrm{df}=9, P=0.926)$. Similarly no significant difference was observed for the F-species among the two habitats (F-species, mean $=0.188 \pm 1.19$ IRA, $t=0.721$, $\mathrm{df}=20, P=0.479$ ). Wilcoxon sign rank tests also showed similar results for the $\mathrm{f}$-species as well as the s-species between the two habitats ( $\mathrm{f}$ species $Z$-test $=-1.274, P=0.203$; s-species $Z$-test $=-1.036$, $P=0.30)$. The relative abundance of s-species between the thicket grassland and typical grassland habitats was not different (s-species, mean $=-0.35 \pm 1.22 \mathrm{IRA}, t=-0.855, \mathrm{df}=$ $8, P=0.417)$. Further, the birds were structured under eight primary feeding guilds: insectivore, granivore, carnivore, frugivore, nectarivore, piscivore omnivore, and predators. Significantly more bird guilds were recorded in the bushland ( $n=8$ feeding guilds) than in other types of habitats $(n \leq 6$ feeding guilds) and constituted most of the forest dependent birds (FF- and F-species). Most of the birds feed primarily on insects. Both insectivores and granivores abundances were not significantly different between bushland and the wooded grassland habitats (insectivores, $Z$-test $=-0.224, P=0.823$; granivores, $Z$-test $=-0.718, P=0.473$ ). Similar results were observed for the piscivores and predatory groups between the two habitats (piscivores, mean $=-0.113 \pm 0.709$ IRA, $t=-0.491, \mathrm{df}=7, P=0.665$; predators, mean $=-0.619 \pm 1.31$ IRA, $t=-1.56, \mathrm{df}=10, P=0.148$ ).

\section{Discussion}

The current study provides insights into the avifaunal assemblages of this coastal protected area. A lack of similar studies conducted prior to the gazettement of the national park limits any further evaluation of the effect of conservation efforts on the bird community structure since then. Results of our study thus serve as a baseline for monitoring future trends of the bird communities and for evaluating conservation and management efforts over time. Species relative abundance was overall high in the surveyed area with some species occurring locally overabundant and widespread than others particularly those feeding on grains/fruits and/or insects. This could be attributable to the local differences in species ecological adaptation that has enabled some species to occupy a wide-habitat range. Streptopelia capicola depicts such an example. The species feeds on both grains and fruits and was recorded in the bushland habitat throughout the surveyed area, suggesting an abundance of seeds and fruits. Although bird abundance and diversity have been found to strongly correlate with habitat quality in terms of food and habitat cover [29] we do not yet have quantitative data on the arthropod abundance or species richness for the surveyed area or its vegetation structure and plant diversity. However, the abundant feeding and ecological guilds observed in our study suggest that the surveyed area may well constitute diverse microhabitats that support different bird species [29]. Our study did not measure habitat structure to enable us to evaluate the influences of such variables as canopy cover and vegetation height on the bird communities. Such analyses could reveal different patterns of community structure and, thus, underscore the need for continued monitoring to guide local management activities that have far-reaching impacts on the habitat quality and local bird community structure $[29,30]$.

High species richness and diversity of the birds observed within the study area provide evidence for the biological richness and importance of the coastal forests to the avifaunal assemblages and hence highlight the area's conservation significance both regionally and internationally [2]. Variation in species richness and diversity between sites may suggest availability of important habitats and resources used by the birds in these sites. This is consistent with a previous vegetation study which indicates relatively higher percentage cover of various vegetation types occupying the north Mkwaja and a bushland/grassland ratio that is overall three times higher than in the south Saadani encompassing the Kinyonga and Saadani Gate blocks [12]. Such variation in the vegetation structure could have come about due to different disturbance regimes under which these sites went through particularly when one part of the area (north Mkwaja and south Mkwaja) was under cattle ranching while south Saadani was a game reserve. The abandonment of the cattle ranch and subsequent protection of this area could have improved habitats leading to significant turnover in species richness and diversity [31, 32]. Our results indicate that the Mkwaja block had more diverse habitat types than other sites, possibly leading to higher species diversity compared to other sites [12]. Further, the asymptotic and nearing plateau of the accumulation curve indicated that our sampling collected a significant number of species available in the study area.

Our study observed bird communities distributed in four ecological guilds including forest specialists, generalists, forest visitors, and savanna or open woodland species. These functional groups occurred all across the surveyed localities although they differed locally in abundances owing to the heterogeneous vegetation in the respective sites. This further suggests that the area provides suitable habitats with adequate food resources (such as insects, nectars, fruits, grains, 
and meat), nesting sites, and protective cover. The highest abundance of the s-species was expected given that largest proportion of the study area is mostly savanna and open woodland vegetation characteristic of the eastern African ecoregion [19]. Further, the area has demonstrated conservation significance due to harboring globally threatened species of birds, including both forest dependent and savanna species. The majority of bird species are in the insectivore group, the most disturbance-sensitive foraging guild [30]. There is the potential for these species being influenced by some inherent disturbances such as management or accidental fires occurring in the area. While we also remain cautious in linking such fires to the local abundances and diversity of birds in Saadani National Park due to the fire either diminishing or promoting local bird diversity elsewhere [33, 34], some evidence from the study area (e.g., [35]) indicate that such fires change soil nutrient dynamics and limit biomass production. Forest fire may cause both short-term and long-term effects influencing habitat quality including cover and food resources such as seeds, fruits, and insects which birds depend on [36-38]. Currently, however, we do not know the type of fruiting plant species available in the area and their phenological patterns and how fires may affect resources such as nectars and fruits productivity. As we start gathering information for this particular area, continued monitoring should be a priority to provide answers to these important questions. Such information will provide appropriate management and conservation recommendations for the threatened bird species and other biota in this ecosystem.

4.1. Implication for Conservation. The survival of forest dependent species will greatly depend on maintaining intact habitats and microhabitats as many species are likely to decrease if such niches disappear. The frequency of wildfires and its potential impact on the forest dependent species should not be ignored in the local management endeavours. Insectivores are the most likely group of bird to be impacted the most as they are highly sensitive to habitat disturbance [30] unlike frugivores and omnivores species which are generally more tolerant of habitat disturbance [39]. Therefore, the persistence of high diversity within bird communities will greatly depend on the managers' ability to maintain heterogeneous vegetation cover $[40,41]$. The current protected status of the area may not guarantee the long-term persistence of the species already threatened with extinction unless deliberate efforts are taken to conserve important habitats and microhabitats for these birds. The species threatened with extinction risks are mostly forest specialist, FFspecies (e.g., Anthreptes pallidigaster), and forest generalist, F-species (e.g., Tauraco fischeri) signaling that their niches are already threatened. The unique habitats and microhabitats currently utilized by these species are not fully understood. Managers should strive to understand these microhabitats and take initiatives to preserve or at least keep them free from disturbances lest they will soon vanish. Such efforts should also target at conserving important niches for the vulnerable and near threatened species such as predatory bird species (Trigonoceps occipitalis, Terathopius ecaudatus), insectivores (Coracias garrulus, Anthreptes reichenowi), frugivores (Tauraco fischeri), and omnivore species (Bucorvus leadbeateri). Furthermore, our study covered only a limited area (within a stretch of $50 \mathrm{~km}$ ); hence these data may not be representative of the whole Saadani National Park. The other part of the park (i.e., north and central parts) that had been extensively used for cattle ranching are now recovering following ranch abandonment and subsequent declaration of the area as a national park $[9,12]$. Due to the continuing successional dynamics of the vegetation and invertebrate assemblages, these segments may support different bird species and communities and therefore call for a continued monitoring of the bird communities in this area.

\section{Conflict of Interests}

The authors declare that there is no conflict of interests regarding the publication of this paper.

\section{Acknowledgments}

This work was supported by funds provided through a field practical training program of Sokoine University of Agriculture in the Faculty of Forest and Nature Conservation. The authors thank Andrew Bowkett for providing comments on earlier drafts of the paper.

\section{References}

[1] N. D. Burgess, G. P. Clarke, and W. A. Rodgers, "Coastal forests of eastern Africa: status, endemism patterns and their potential causes," Biological Journal of the Linnean Society, vol. 64, no. 3, pp. 337-367, 1998.

[2] E. T. Azeria, I. Sanmartín, S. Ås, A. Carlson, and N. Burgess, "Biogeographic patterns of the East African coastal forest vertebrate fauna," Biodiversity and Conservation, vol. 16, no. 4, pp. 883-912, 2007.

[3] D. Sheil, "Tanzanian coastal forests-unique, threatened, and overlooked," Oryx, vol. 26, no. 2, pp. 107-114, 1992.

[4] S. N. Hassan, A. Salum, A. A. Rija, R. Modest, J. R. Kideghesho, and P. F. Malata, "Human-induced disturbances influence on bird communities of coastal forests in eastern Tanzania," British Journal of Applied Science \& Technology, vol. 3, pp. 48-64, 2013.

[5] WWF, "Protecting East Africa's coastal forests," 2009, http://www.panda.org.

[6] N. D. Burgess, K. L. Ponder, and J. Goddard, "Surface and leaflitter arthropods in the coastal forests of Tanzania," African Journal of Ecology, vol. 37, no. 3, pp. 355-365, 1999.

[7] H. Y. D. Kiwia, "Species richness and abundance estimates of small mammals in Zaraninge coastal forest in Tanzania," Tanzania Journal of Science, vol. 32, no. 2, pp. 105-116, 2009.

[8] C. Mligo, H. Lyaruu, H. Ndangalasi, and R. Marchant, "Vegetation community structure, composition and distribution pattern in the zaraninge forest, bagamoyo district, Tanzania," Journal of East African Natural History, vol. 98, no. 2, pp. 223239, 2009.

[9] A. C. Treydte, P. J. Edwards, and W. Suter, "Shifts in native ungulate communities on a former cattle ranch in Tanzania," African Journal of Ecology, vol. 43, no. 4, pp. 302-311, 2005. 
[10] T. M. Palmer, M. L. Stanton, T. P. Young, J. R. Goheen, R. M. Pringle, and R. Karban, "Breakdown of an ant-plant mutualism follows the loss of large herbivores from an African Savanna," Science, vol. 319, no. 5860, pp. 192-195, 2008.

[11] R. Cochard and P. J. Edwards, "Tree dieback and regeneration in secondary Acacia zanzibarica woodlands on an abandoned cattle ranch in coastal Tanzania," Journal of Vegetation Science, vol. 22, no. 3, pp. 490-502, 2011.

[12] M. W. Tobler, R. Cochard, and P. J. Edwards, "The impact of cattle ranching on large-scale vegetation patterns in a coastal savanna in Tanzania," Journal of Applied Ecology, vol. 40, no. 3, pp. 430-444, 2003.

[13] R. Cochard and P. J. Edwards, "Structure and biomass along an Acacia zanzibarica woodland-savanna gradient in a former ranching area in coastal Tanzania," Journal of Vegetation Science, vol. 22, no. 3, pp. 475-489, 2011.

[14] R. Leemans and B. Eickhout, "Another reason for concern: regional and global impacts on ecosystems for different levels of climate change," Global Environmental Change, vol. 14, no. 3, pp. 219-228, 2004.

[15] P. A. Robertson and D. Liley, "Assessment of sites: measurement of species richness and diversity," in Expedition Field Techniques. Bird Surveys, C. Bibby and M. Jones, Eds., chapter 5, pp. 7698, Expedition Advisory Centre, Royal Geographical Society, London, UK, 1998.

[16] J. Mackinnon and K. Phillips, A Field Guide to the Birds of Sumatra, Java and Bali, Oxford University Press, Oxford, UK, 1993.

[17] J. Fjeldså, "The impact of human forest disturbance on the endemic avifauna of the Udzungwa Mountains, Tanzania," Bird Conservation International, vol. 9, no. 1, pp. 47-62, 1999.

[18] F. P. Jensen, A. P. Tøttrup, and K. D. Christensen, “The avifauna of coastal forests in southeast Tanzania," Scopus, vol. 25, pp. 122, 2005.

[19] D. A. Zimmerman, D. A. Turner, and D. J. Pearson, Birds of Kenya and Northern Tanzania, Christopher Helm Publishers, London, UK, 1999.

[20] T. Stevenson and J. Fanshawe, Birds of East Africa: Kenya, Tanzania, Uganda, Rwanda and Burundi, T and AD Poyser Ltd, London, UK, 2002.

[21] P. Ryan and I. Sinclair, Birds of Africa South of the Sahara, vol. 2nd, Struik Nature Cape Town-Malaysia, 2010.

[22] B. O. Poulsen, N. Krabbe, A. Frølander, M. B. Hinojosa, and C. O. Quiroga, "A rapid assessment of Bolivian and Ecuadorian montane avifaunas using 20-species lists: efficiency, biases and data gathered," Bird Conservation International, vol. 7, no. 1, pp. 53-67, 1997.

[23] N. J. Gotelli and R. K. Colwell, "Quantifying biodiversity: procedures and pitfalls in the measurement and comparison of species richness," Ecology Letters, vol. 4, no. 4, pp. 379-391, 2001.

[24] L. Bennun, C. Dranzoa, and D. Pomeroy, "The forest birds of Kenya and Uganda," Journal of East African Natural History, vol. 85, no. 1, pp. 23-48, 1996.

[25] R. K. Colwell, EstimateS: "Statistical Estimation of Species Richness and Shared Species from Samples", Version 8.2, 2012, http://purl.oclc.org/estimates.

[26] R. K. Colwell and J. A. Coddington, "Estimating terrestrial biodiversity through extrapolation," Philosophical Transactions of the Royal Society of London B: Biological Sciences, vol. 345, no. 1311, pp. 101-118, 1994.
[27] A. E. Magurran, Measuring Biological Diversity, Blackwell, New York, NY, USA, 2004.

[28] R. Naidoo, "Species richness and community composition of songbirds in a tropical forest-agricultural landscape," Animal Conservation, vol. 7, no. 1, pp. 93-105, 2004.

[29] J. Tews, U. Brose, V. Grimm et al., "Animal species diversity driven by habitat heterogeneity/diversity: the importance of keystone structures," Journal of Biogeography, vol. 31, no. 1, pp. 79-92, 2004.

[30] Ç. H. Sekercioglu, P. R. Ehrlich, G. C. Daily, D. Aygen, D. Goehring, and R. F. Sandí, "Disappearance of insectivorous birds from tropical forest fragments," Proceedings of the National Academy of Sciences of the United States of America, vol. 99, no. 1, pp. 263-267, 2002.

[31] J. Barlow and C. A. Peres, "Avifaunal responses to single and recurrent wildfires in Amazonian forests," Ecological Applications, vol. 14, no. 5, pp. 1358-1373, 2004.

[32] R. K. Mulwa, K. Böhning-Gaese, and M. Schleuning, "High bird species diversity in structurally heterogeneous farmland in Western Kenya," Biotropica, vol. 44, no. 6, pp. 801-809, 2012.

[33] J. Barlow, C. A. Peres, L. M. P. Henriques, P. C. Stouffer, and J. M. Wunderle, "The responses of understorey birds to forest fragmentation, logging and wildfires: an Amazonian synthesis," Biological Conservation, vol. 128, no. 2, pp. 182-192, 2006.

[34] K. E. Bagne and K. L. Purcell, "Short-term responses of birds to prescribed fire in fire-suppressed forests of California," The Journal of Wildlife Management, vol. 75, no. 5, pp. 1051-1060, 2011.

[35] P. G. Cech, H. Olde Venterink, and P. J. Edwards, "N and P cycling in Tanzanian humid savanna: influence of herbivores, fire, and N2-fixation," Ecosystems, vol. 13, no. 7, pp. 1079-1096, 2010.

[36] T. Haugaasen, J. Barlow, and C. A. Peres, "Effects of surface fires on understorey insectivorous birds and terrestrial arthropods in central Brazilian Amazonia," Animal Conservation, vol. 6, no. 4, pp. 299-306, 2003.

[37] K. E. N. Green and G. Sanecki, "Immediate and short-term responses of bird and mammal assemblages to a subalpine wildfire in the Snowy Mountains, Australia," Austral Ecology, vol. 31, no. 6, pp. 673-681, 2006.

[38] J. W. F. Slik and S. Van Balen, "Bird community changes in response to single and repeated fires in a lowland tropical rainforest of eastern Borneo," Biodiversity and Conservation, vol. 15, no. 14, pp. 4425-4451, 2006.

[39] L. G. L. Gomes, V. Oostra, V. Nijman, A. M. Cleef, and M. Kappelle, "Tolerance of frugivorous birds to habitat disturbance in a tropical cloud forest," Biological Conservation, vol. 141, no. 3, pp. 860-871, 2008.

[40] C. A. Harvey, A. Medina, D. M. Sánchez et al., "Patterns of animal diversity in different forms of tree cover in agricultural landscapes," Ecological Applications, vol. 16, no. 5, pp. 1986-1999, 2006.

[41] W. D. Kissling, C. Rahbek, and K. Böhning-Gaese, "Food plant diversity as broad-scale determinant of avian frugivore richness," Proceedings of the Royal Society B: Biological Sciences, vol. 274, no. 1611, pp. 799-808, 2007. 

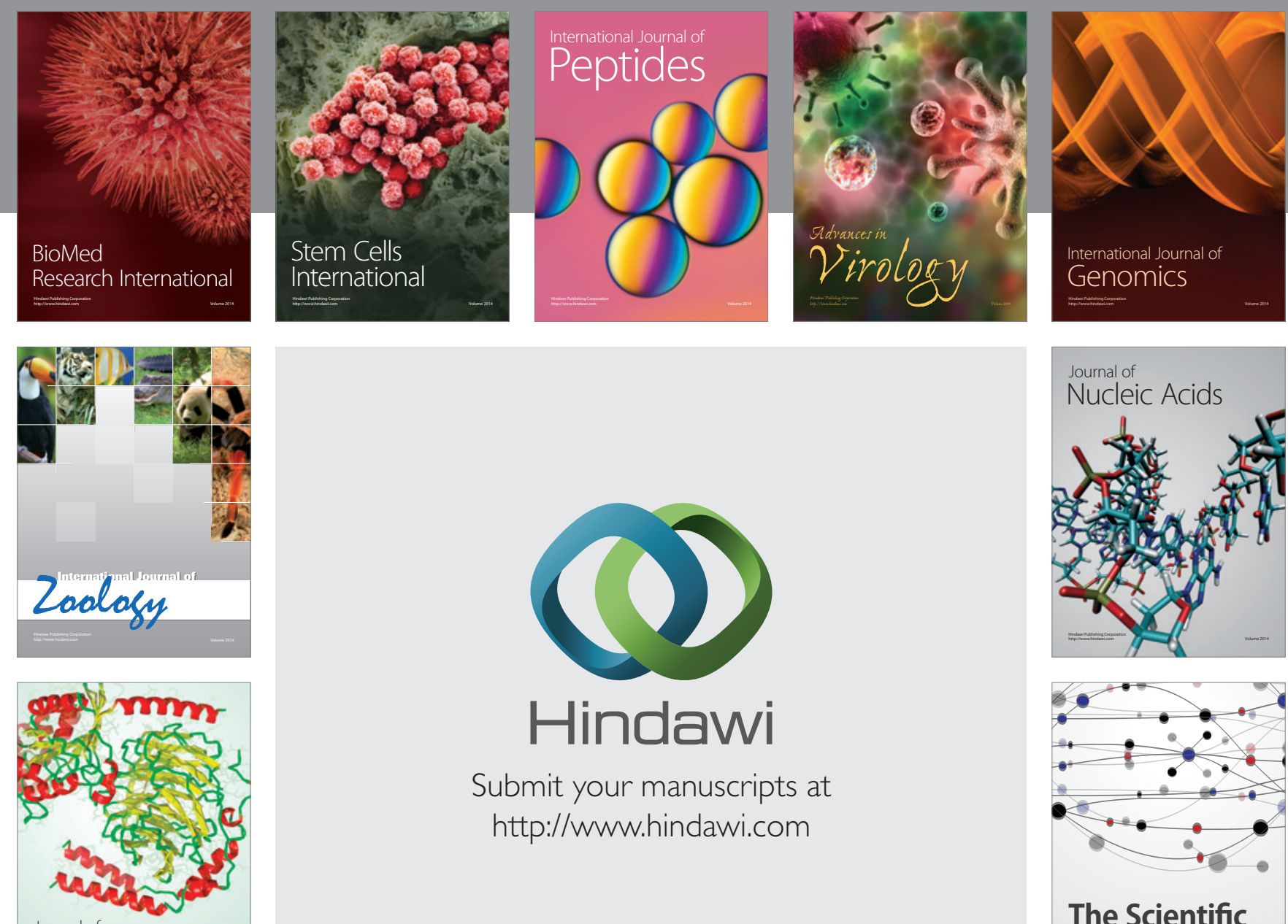

Submit your manuscripts at

http://www.hindawi.com

Journal of
Signal Transduction
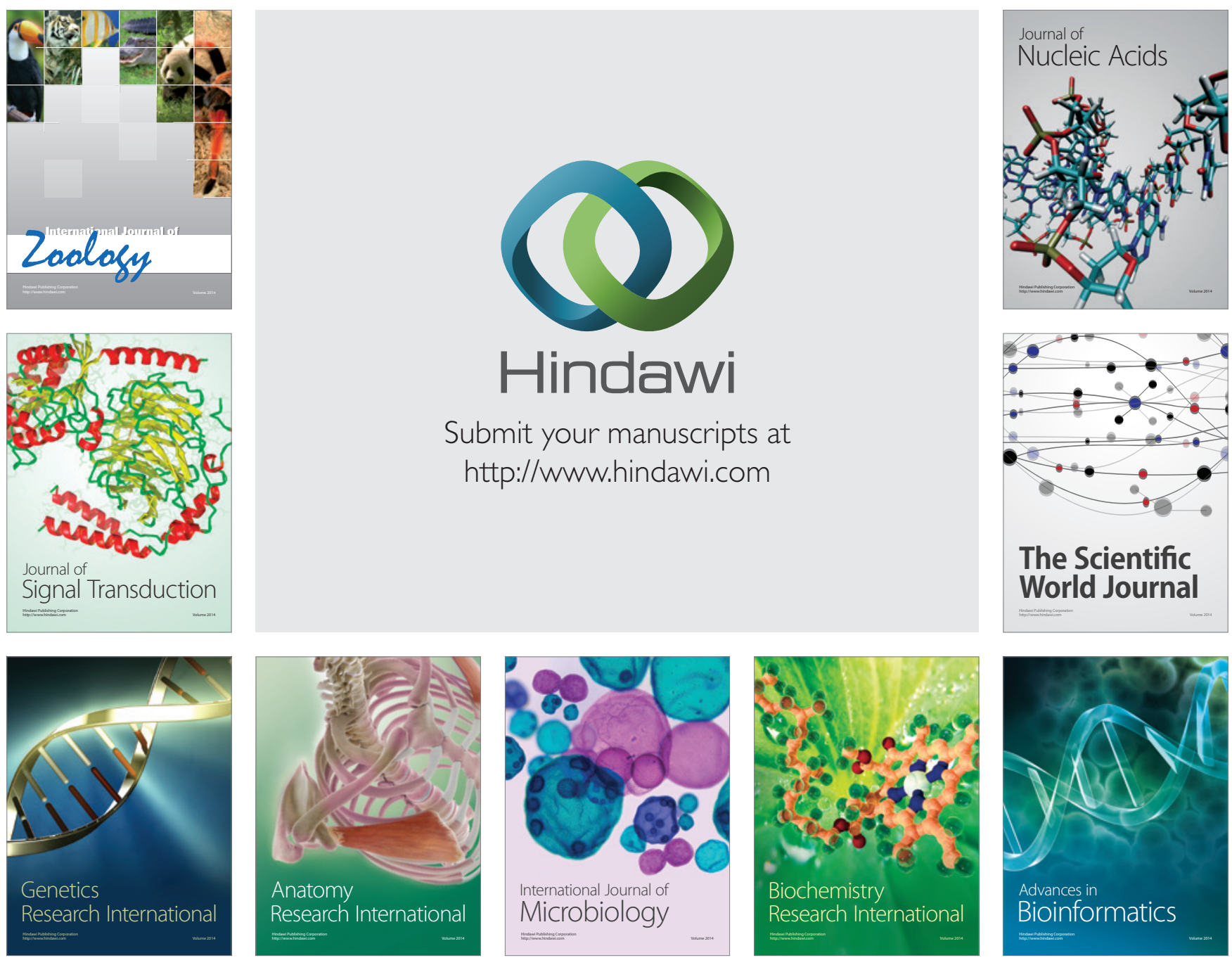

The Scientific World Journal
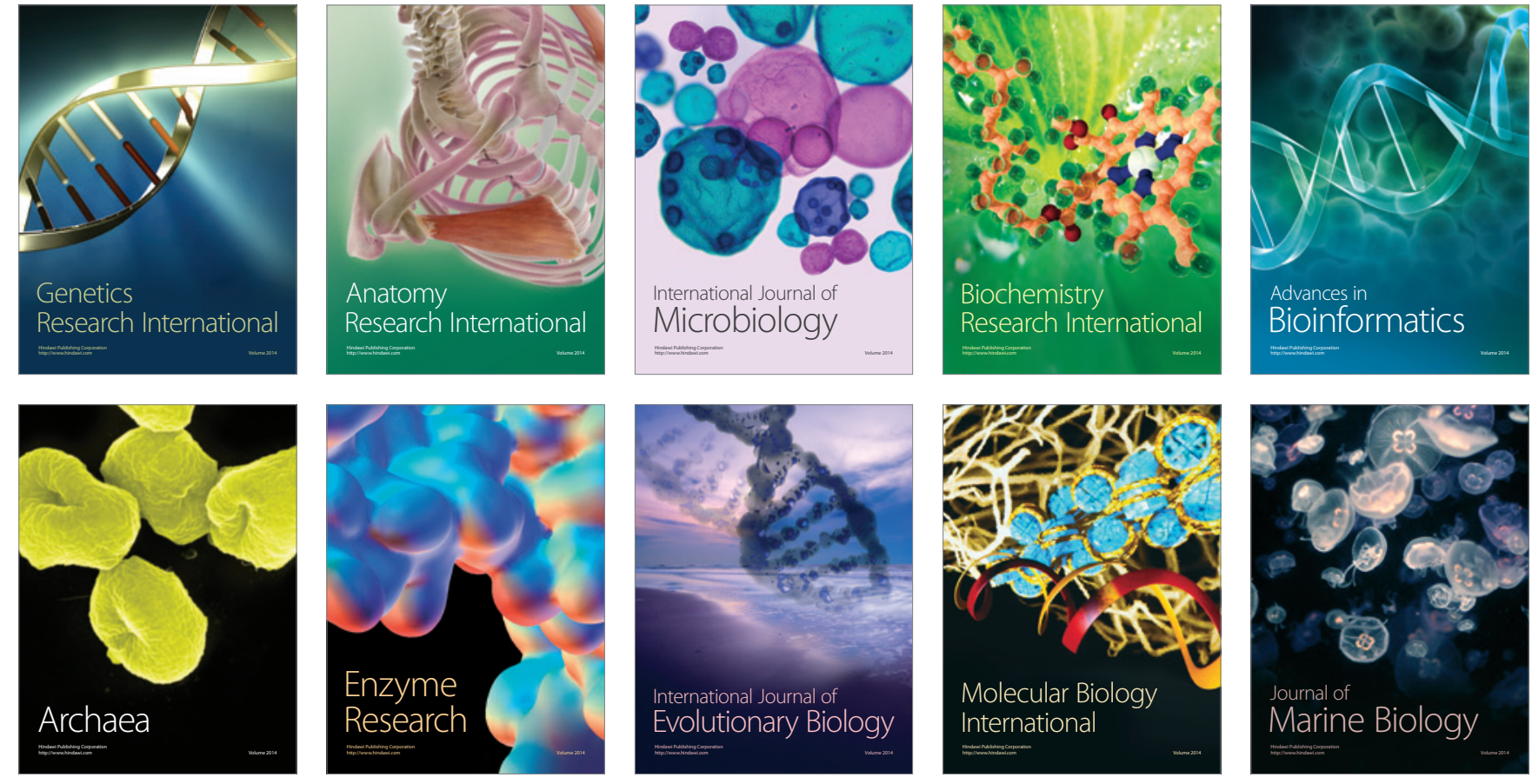